\title{
ANALISIS ISYTIQAQ DALAM KAJIAN FIKIH LUGHAH DAN PENGAJARANNYA
}

\author{
Devy Aisyah \\ Dosen Program Studi Pendidikan Bahasa Arab, Jurusan Tarbiyah, STAIN Batusangkar \\ Korespondensi: Komplek Perumahan Simonai, Lima Kaum, Batusangkar, Sumatera Barat \\ e-mail: devy.aisyah@yahoo.co.id
}

\begin{abstract}
The study of Istisqaq (derivational word) as a part of Fiqh lughah (Arabic linguistic) is a main concern of linguists in the recent decade. Istisqa' is one of the distinguished features of Arabic which have rich vocabulary. In the early of the third century of Hijriah year, several Ulamas (Moslem scholar) pay a serious attention in the study of Istisqaq. Istisqaq is a process of forming a word to another word in order to produce a new meaning. This formation was initiated by Ibn Jinniy. He then wrote a monumental book entitled Al-Khashaish. Istisqaq is identical with the study of Ilm Syarf (morphology). This paper concludes that the teaching of fiqh lughah in an advanced level needs to improve. In addition to this, the addition of language structure could be taught contextually and communicatively.
\end{abstract}

Kata kunci: analisis, isytiqaq, fikih lughah.

\section{PENDAHULUAN}

$I$ sytiqaq menjadi salah satu karakteristik yang paling unik yang dikenal dalam kajian ilmu bahasa Arab sekaligus menjadi pembahasan yang sangat menarik di kalangan pemerhati bahasa Arab. Fenomena isytiqaq dalam kajian Bahasa Arab sudah dikenal dan ditulis oleh ulama-ulama Bahasa Arab terdahulu di dalam kitab mereka seperti: Ibn Faris dalam bukunya $\mathrm{Al}$ Shahibiy fi Fikh al-Lughah al-'Arabiyah wa Masailiha Wa Sunan al-'Arab fi Kalamiha, dan juga Ibn Jinniy dalam karyanya al-Khashaish, serta al-Muzhir fì 'Ulum al-;Arabiyah karya Jalaluddin al-Suyuthi. (Suyuthi, Tp.Th: 345).

Sedangkan dalam beberapa buku Fikih Lughah modren, terma tentang isytiqaq ini selalu menjadi topik yang menarik dan penting dikaji secara rinci. Adapun kitab Fikih Lughah modren yang menjelaskan tentang isytiqaq antara lain: Amil Badi' Ya'qub dengan karyanya "Fikih Lughah al-'Arabiyah wa Khashaisuha", "Fushul Fiy Fikh al'Arabiyyah" karya Ramadhan Abd alTawwab, serta "Fikh al-Lughah Wa Khashaish al-'Arabiyyah" karya Muhammad Mubarak. (Mubarak, Tp. Th: 69).

Menurut analisa penulis, Isytiqaq telah menjadi suatu disiplin ilmu yang berdiri sendiri. Istilah Isytiqaq disepadankan dengan istilah Linguistik Modern, yang dikenal dengan etimologi, yang artinya suatu cabang ilmu yang mengkaji tentang asal usul suatu kata. Adapun klasifikasi Isytiqaq dalam Linguistik Arab menjadi salah satu perdebatan di kalangan ulama Bahasa Arab. Pro dan kontra di kalangan ulama tentang keberadaan isytiqaq dalam kancah Ilmu Bahasa Arab inilah yang 
menjadi hal yang paling menarik untuk dikaji. Berdasarkan uraian di atas, penulis akan menjelaskan secara eksplisit dan runtut mengenai sekelumit tentang "Analisis isytiqaq dalam kajian Fikih Lughah".

\section{PENGERTIAN ISYTIQAQ}

Secara etimologi, lafaz اشتقاق adalah shighat mashdar dari lafaz yang berarti mengambil dan memecah dan membelah. Ini dicontohkan pada serangkaian kata انتق yakni artinya mengambil suatu kata dari yang lainnnya. (Ma'luf, 1992: 396)

Amil Badi' Ya'qub juga mendefinisikan, الإثتقاق في اللغة هو أخذ شق الثيء artinya mengambil pecahan sesuatu. (Ya'qub: Tp.Th: 186). Sedangkan secara terminologi, berbagai definisi yang disampaikan oleh para para pakar Bahasa Arab antara lain:

1. Dr.Amil Badi'Ya'qub

$$
\text { أخذ كلمة من أخري بتغيير ما مع التناشب في }
$$

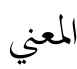

Mengambil suatu kata dari lainnya dengan cara merubah namun tetap mempunyai hubungan makna. (Ya'qub, Tp.Th.187).

2. Dr.Subhi Shaleh

$$
\text { أوليد لبعض الألفاظ من بعض والرجوع بها إلي }
$$

Membentuk satu kata dari kata lainnya dan mengembalikan kepada aslinya yang sesuai dengan materinya dengan memmberikan makna yang baru. (Shaleh,Tp.Th: 187).

Dari kedua definisi di atas, dapat dipahami bahwa isytiqaq adalah salah satu cara atau proses pembentukan suatu kata menjadi kata lain sehingga terjadi perubahan bentuk dan memberi makna baru. Menurut hemat penulis, dalam isytiqaq poin yang penting diketahui adalah: 1. Ada kata asal 2. Ada kata lain yang akan dibentuk dari huruf asal 3 . Ada kesamaan kata asal dengan kata yang akan dibentuk dari sisi huruf asal 4 . Ada sisi kesamaan makna dan terjadi makna yang baru. Contoh. kata - صام يصوم - . Secara berurutan artinya: seacara berurutan "berpuasa", "dia sedang berpuasa"," puasa", "orang yang berpuasa", dan "janganlah kamu berpuasa".

Isytiqaq disebut juga derivasi kata atau penurunan kata yaitu mengambil satu kata atau sebagiannya dari kata dasarnya. Penurunan kata berlaku pada bentuk kata benda yang biasa disebut dengan mashdar. Ini disebabkan karena aktifitas atau peristiwa yang berkaitan dengan pembentukan dari suatu keadaan sesuai dengan perbedaan sifat, waktu atau tempat terjadi. Seperti al-kitabah, merupakan mashdar yang menunjukkan suatu peristiwa. Jika dari kata itu diambil kata yaktubu maka kata itu menunjukkan pekerjaan yang dilakukan pada masa yang akan datang dan masa sekarang. Jika dibentuk dengan kata kataba, maka pekerjaan itu menunjukkan pada masa yang lewat.

Menurut pandangan ulama Barat, isytiqaq ini disebut dengan Etimologi yaitu salah satu cabang ilmu bahasa yang mengkaji tentang mufradat (kosa kata). Adapun bidang kajiannya hanya dibatasi pada pengambilan kata perkata dari kamus disertai dengan penambahannya yang diserupakan dengan tanda pengenal seseorang; dari mana, kapan, bagaimana seseorang itu dan perubahan yang ada padanya. Oleh sebab itu, ilmu historis akan memberi batasan terhadap bentuk kata tersebut. Dimana masa dahulu, ilmu-ilmu sejarah bisa membantu untuk menyelesaikannya dan mengkaji bagaimana cara perubahan yang terjadi pada 
tiap kata ditinjau dari makna dan ditinjau dari isti'malnya. (Tawwab, Tp.Th: 290)

Pendapat Ulama Barat yang menyatakan bahwa etimologi (isytiqaq) bila ditinjau dari aspek makna, maka diklasifikasikan pada ilmu nadzahri 'amaliy; artinya ilmu yang bersifat teoritis lagi praktis yaitu ilmu yang bisa difahami dengan disertai ilmu sejarah tentang kata dan adanya penelusuran perkembangannya melalui masa yang berbeda-beda. (Tawwab, Tp.Th: 290.)

Sedangkan menurut Ulama Arab, isytiqaq adalah ilmu 'amaliy thathbiqiy, artinya ilmu yang bersifat praktis dan aplikatif yakni ilmu yang mengkaji tentang proses pembentukan kata dengan kata lainnya dan mengembalikan kepada asalnya yang dibatasi pada bentuknya dengan memberi makna yang spesifik lagi baru. Sebagai contoh, isytiqaq kata " kataba /bisa dibentuk pada bermacam bentuk sebagai berikut: كتب /uktub artinya tulislah, كتابة/kitaabah, artinya tulisan, الا تكتب laa taktub, artinya: jangan engkau tulis, dan seterusnya. Dari beberapa perubahan dan penurunan kata "kataba" di atas, terlihat adannya hubungan makna yakni "tulis". Kajian tentang perubahan bentuk setiap kata di atas, adalah salah satu pembahasan pada materi ilmu sharaf (morfologi), yakni satu kata menjadi dasar bagi terbentuknya kata-kata lain.

\section{MACAM-MACAM ISYTIQAQ}

\section{Isytiqaq Shaghir/ Isytiqaq 'Am}

$$
\text { وتشرط الإشتقاق الصغير هو نزع لفظ من آخر اصل منه في المعني والأحرف الأصول }
$$

Isytiqaq Shaghir artinya membentuk beberapa kata dari sebuah kata dasar dengan tetap melihat kesamaan urutan morfemnya seperti pada kata dasarnya.

Isytiqaq Shagir terjadi pada tashrif lughawi dan tashrif ishthilahiy pada fiil madhi, fiil mudhari', fiil amar, mashdar dan seterusnya. Adapun contohnya.

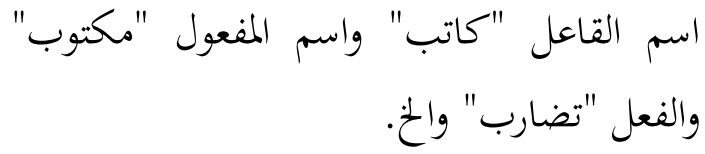

Sebagian Ulama Kuffah menggunakan istilah Isytiqaq, sebagai ganti dari sharaf. Begitu pula Ibn Jinniy, menurutnya antara kedua istilah Isytiqaq dan tashrif mempunyai kaitan yang sangat erat. Istilah Tashrif berarti mendatangkan satu kata lalu merubahnya ke bentuk yang lain, sama halnya dengan istilah Isytiqaq.

Pandangan ini ada benarnya, jika yang dimaksud oleh Ibn Jinny istilah Tashrif atau sharaf adalah bahagian dari Isytiqaq Shagir.

\section{Isytiqaq Kabir/Qalbu Al-Lughawiy}

$$
\text { تناسب في اللفظ والمعني دون ترتيب الحرف أن بين كلمتين }
$$

(Ya'qub, Tp.Th: 198)

Isytiqaq kabir adalah dua kata yang mempunyai persamaan lafaz dan makna tetapi susunan hurufnya tidak sama. Atau dengan kata lain adalah dua kata yang mempunyai persamaan lafaz dan makna namun berbeda dalam urutan huruf.

Contoh: جبذ - جذب مدح-حمد

Isytiqaq Kabir ini disebut pula dengan qalb artinya memutar atau menukar pola tiga huruf menjadi enam pola yang berbeda. Contoh isytiqaq ini, yang dikemukakan oleh Ibn Jinni adalah pemutaran tiga huruf : ج-ب . Dari susunan huruf ini, bagaimanapun posisinya, inti maknanya tetap sama, yaitu: kuat dan sangat. Dari pemutaran susunan huruf ini muncul kata, 
1. Kata جبرت العظم و الفقير : misalnya artinya bila anda memperkuat dan mepereratnya. Al-Jabr artinya berkuasa karena memiliki kekuatan dan karena mampu menopang orang lain.

2. Kata جرب : misalnya رجل :جرب, artinya bila dia tertarik oleh satu hal, lalu dia coba, maka keinginannya akan semakin kuat dan perasaannya akan semakin mengental terhadap hal itu.

Dari kata ini, misalnya adalah الجراب , karena benda ini sangat melindungi segala apa yang ada di dalamnya.

3. Kata الأبجر-البجرة misalnya : بang berarti besar perut, karena hal itu timbul karena kekuatan nafsu dan implikasi yang menyertainya.

4. Kata برج artinya adanya kekuatan dalam diri dan kekuatan lainnya

5. Kata رجبت الرجل misalnya , رجب , artinya bila anda menghormati dan mendukung sesorang itu. Misalnya, seseorang yang didukung untuk melakukan perang, atau bila seseorang menghormati batang kurma, maka dia akan menopangnya dengan رجبة (penopang), yakni sesuatu yang disandarkan ke batangnya untuk memperkuatnya. Sedangkan kata الراجبة adalah salah satu bagian jari tangan, yakni sisi yang memperkuatnya, yaitu sendinya.

6. Kata ربج artinya mengacu pada makna al-Quwwah dan Syiddah.

\section{Isytiqaq Akbar/Al-Badal}

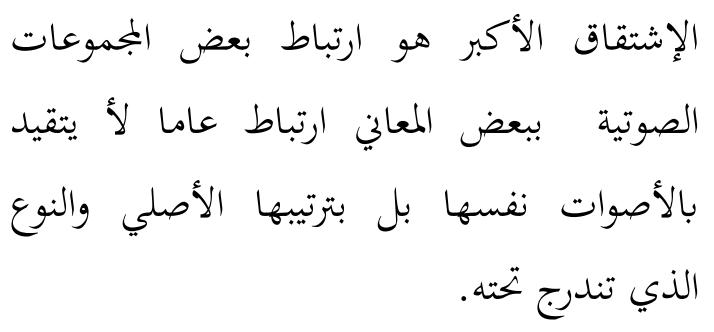

Isytiqaq Akbar adalah menukar suatu huruf dengan huruf lain yang mirip makhrajnya sehingga mudah diucapkan. Contoh Menukar huruf واو menjadi ألف, pada lafaz صوم menjadi صام dan menukar اصتنع paruf menjadi menjadi اصطنع.

\section{Isytiqaq Kubbar/Al-Nahat}

Isytiqaq Kubbar atau al-Naht adalah membentuk satu kata dari dua kata atau lebih dengan maksud untuk menyingkat dan memudahkan ucapan. Menurut Amil Badi' Ya'qub (Ya'qub, Tp.Th: 208)

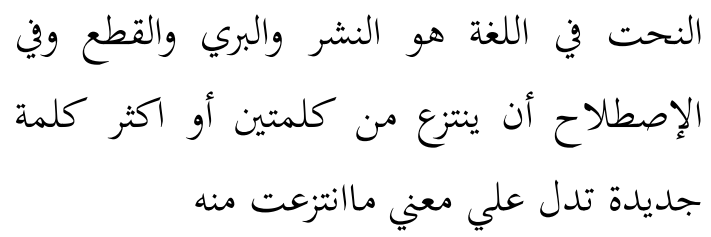

Adapun contohnya dibagi pada empat klasifikasi:

1. Naht Nisbiy adalah menisbahkan atau memberi sifat kepada sesuatu atau kepada seseorang atau terhadap pekerjaan pada dua bentuk isim. Seperti kata عبد الشمس disingkat menjadi dan kata بلحارث disingkat menjadi بني الحارثdan sebagainya.

2. Naht fi'liy artinya membentuk kata dengan mempersingkat suatu kalimat (jumlah) yang diucapkan. Adapun contohnya adalah بسم الله الرحمن الحيم لاحولا disingkat menjadi بسمل dan kata حوقل disingkat menjadi ولا قوة إلا بالله dan sebagainya.

3. Naht isim artinya mempersingkat dua kata menjadi satu isim. Contohnya جلمود disingkat menjadi جلد وبمد

4. Naht Washfiy adalah membentuk dari dua kata menjadi satu kata yang menunjukkan suatu sifat. Adapun 
contohnya: ضبط وضبر disingkat menjadi ضبطر artinya menunjuk sifat lakilaki yang kuat.

Belakangan bahasa Arab menerima bentuk al-naht baru, yaitu:

1. Al-naht al-rumziy (naht simbolik). Ini terbagi dua; pertama al-naht alharf al-rumziy (naht huruf simbol), yaitu naht yang terdiri dari satu atau dua huruf untuk merumuskan sebuah kata, yang diambil dari huruf pertama, atau huruf tengah, atau huruf akhir kata-kata itu, atau dengan tanda lain yang bukan bagian dari hurufnya. Jenis ini banyak dalam bahasa Eropa yang disebut dengan symbol. Dari dulu orang Arab juga sudah mengenal cara ini, misalnya huruf $p$ sebagai tanda waqaf lazim, ثنا untuk kalimat dan lain-lain. Tujuan pembuatan naht ini adalah untuk memudahkan, menghemat tenaga dan mempersingkat waktu. Contoh kontemporernya adalah seperti د دكتور =Dr, سم = =Cm.

Kedua, al-naht al-awa'iliy, yaitu naht yang dibentuk dengan menggabungkan huruf-huruf awal beberapa kata sehingga membentuk sebuah istilah, yang dalam bahasa Inggeris disebut acronym. Akronim banyak dipergunakan untuk menyebut lembaga atau organisasi nasional dan internasional.

Misalnya, أوبيك (OPEC), اليونسكو

(UNESCO), النـاتو (NATO), الإيــز

(AIDS), الناسا (NASA), إيزو (ISO).

2. Al-Naht min al-Murakkabat, atau alTarkib al-Majziy, yaitu gabungan dua kata dan menjadikannya sebuah nama tanpa mengurangi bentuk manapun dari keduanya. Contoh klasik adalah kata رامهرمز ,حضرموت ,بعلبك. Penggabungan kata jenis ini dibuat dengan mengurangi huruf-huruf asli dan merobahnya, lalu digabung membentuk satu kata. Contoh lain, adalah kata اصطر+ لابون berasal dari, ساء من رأى berasal dari سامراء data kata atau سر من رأى.

Naht tarkib mazjiy ini ada tiga macam:

a. al-Naht wa al-Tarkib, dua sisi yang menunjukkan satu hakikat ketika telah disatukan antar unsur-unsur aslinya untuk membentuk istilah bahasa baru. Jenis ini digunakan untuk nama tokoh atau lainnya, seperti نيولدلهي , عربستان , سيبويه, . Jenis ini, termasuk murakkab ittiba'iy untuk menyebut keterangan waktu dan tempat serta sifat, seperti: بين بين dan صباح مساء. Pada era kontemporer dan modern misalnya kata أنجلـو سكسـون (anglosaxon), أنجلو أمريكى (anglo amerika). Termasuk juga susunan campuran beberapa istilah, misalnya kata: كهر = elektro, الكهر الكهربي , مغنتية (electromagnetism), هـائي حركي (hydroelectric), هـي (aerodynamics) dan sebagainya.

b. Al-Naht al-Muwafaq yaitu konvigurasi sempurna antar beberapa kata yang telah terkenal penggunaannya. Misalnya kata: البسملة dibuat setelah bismillah terkenal, حراري نواوي setelah kata حرّنوي dikenal sebagai terjemahan 
thermonuclear. Contoh lain: kata مازهر gabungan dari kata ماء + زهر kata ماورد gabungan dari kata ماء +ورد Contoh kontemporer adalah kata فحميل yang artinya carbonyle, نمليـل yang artinya formyle, غوليلartinya alcoyle.

c. Al-Naht al-Khas, ada dua bentuk, pertama, istilah-istilah yang berasal dari isim, huruf, dan عن و ) العنعنة dhamir. Misalnya kata (كن berasal dari ( كيف b), berasal dari ( الماهية قبتاريخ berasal dari (قبـلتاريخ ). Bentuk kedua, susunan penegasian (la nafiyah) yang ditambah dengan alif lam di awalnya. Contoh, kata اللامركزي , الامحدودي (unlimited),

(decentralisation),

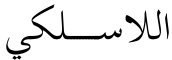

(wireless), اللأخلاقي (amoral), اللاتناظري (asymmetrical) (Shadiq Qunaibiy, 2000;189-203).

\section{PENGAJARAN/PEMBELAJARAN FIKIH LUGHAH TENTANG ISYTIQAQ}

Pengajaran Fikih Lughah adalah bagian pengajaran pada bidang kebahasaan (lughah). Fikih Lughah atau Linguistik Arab sangat sarat dengan kajian fenomena-fenomena bahasa Arab seperti adanya isytiqaq: apakah itu pembahasan tashrif, al-nahat (singkatan), maupun istilah-istilah asing yang masuk pada wazan-wazan Arab. Contoh singkatan حوقل adalah kependekan dari lafaz Laa Haulaa Wa Laa Quwwata Illaa Billahil "aliyyil 'Adziim. Contoh lain adalah singkatan dari kalimat ini adalah singkatan dari مكتب البريد

Contoh di atas adalah bahagian kecil dari materi yang dikaji pada fikih lughah. Orang yang belajar fikih lughah, akan mudah memahami materi ilmu ashwat, materi mufradat dan materi kitabah. Sebaliknya pelajar/mahasiswa yg tidak atau belum mempelajari fikih lughah agak kesulitan dalam menguasai ilmu ashwat, mufradat, dan ilmu sharfi. (Ahmad Tha'imah, 1989: 36-39). Salah satu karakteristik dan keistimewan Bahasa Arab adalah berkembangnya fenomena isytiqaq. Pengajaran bahasa Arab untuk non Arab dalam hal ini Fikih Lughah merupakan salah satu cara yang sudah dikenal untuk menyebarkannya ke seluruh dunia. Untuk itu orang Arab telah berusaha dengan berbagai cara dan pengorbanan serta mencanangkan berbagai program. Media pengajaran paling penting mereka disediakan untuk pengajaran bahasa Arab bagi non Arab adalah buku-buku pengajaran bahasa yang relevan dan sesuai dengan daya pikir dan emosi peserta, baik untuk muhadtsah, kitabah, maupun untuk kemahiran berbahasa lainnya. Semua sarana ini dibuat demi memudahkan non Arab mempelajari dan mengajarkan bahasa Arab. Bahasa Arab mempunyai beberapa karekteristik dan keistimewaan yang membedakannya dengan bahasa lain. Di antara karekteristik itu secara umum adalah,

1. Mempunya isytiqaq dan shighat untuk membuat kata baru dari akar kata.

2. Mempunyai bunyi yang kaya karena banyaknya makhraj huruf dan harkat.

3. Mempunyai sistim I'rab karena ada sejumlah aturan penyusunan kata dan menentukan fungsi kata itu serta menentukan baris akhirnya, yang sangat membantu dalam mendapatkan pemahaman akurat. 
4. Kaya dengan model ta'bir dan uslub kalimat.

5. Mempunyai ciri khas penulisan huruf (Ahmad Tha'imah, 1989:3639).

Bagi pelajar yang sudah belajar fikih lughah, biasanya mereka akan mendenganr bunyi huruf dengan benar dan melafazkannya dengan lancar dan membaca teksnya Arab dengan baik.

Kemahiran mendengar para siswa akan terbentuk antara lain karena baiknya kata yang dipakai dan bagusnya pelafalan kata itu oleh pengajar. Para pengajar mestinya membuat contoh dengan kalimat yang tidak menggunakan kata serapan Arab supaya pengucapannya bagus sehingga para pelajar dapat mendengar dengan jelas serta bisa mengikuti pelafalan. Bandingkan beberapa kalimat berikut dalam hal kemudahan dan kesulitan pelafalannya:

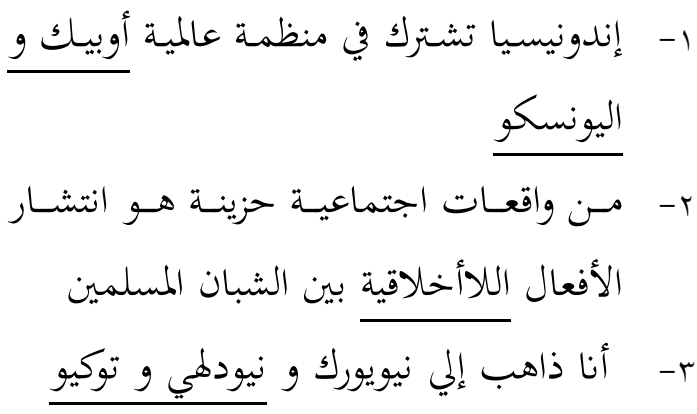

\section{SIKAP DAN PENDAPAT ULAMA}

Para ulama Bahasa Arab, sebenarnya tidak semua sepakat terhadap fenomena isytiqaq ini. Karena adanya perbedaan cara pandang dan alasan mereka dalam memahami dan memberikan contoh isytiqaq. Perbedaan pandangan tentang Isytiqaq ini mulai dari pemahaman mereka tentang definisi, ruang lingkup dan asal usul kata-kata yang dibentuk. Kajian tentang isytiqaq ini sudah mulai muncul pada abad ketiga Hijrah yang dibuktikan dengan lahirnya Kitab karya al-Zujjaj dan al-Mubarrad. Sehingga pada pertengahan abad ke-4, kajian tentang isytiqaq ini hanya sampai pada kajian tentang adanya kesesuaian antara kata-kata terhadap lafaz dan maknanya serta urutan huruf pada kata-kata tersebut. Seperti جلس-يجلس-جلوس. Namun seorang tokoh Ibn Jinniy pada akhir abad ke-4 adalah tokoh yang sangat kreatif dan mumpuni yang mencoba menambahkan satu fashal khusus lagi tentang kata-kata yang diambil dari kata lain dengan dibolak-balik urutannya tetapi memiliki makna yang sama secara umumnya yaitu Isytiqaq Kabir atau al-Qalab.

Menyikapi adanya isytiqaq shaghir, sebagian ulama berbeda pendapat tentang batasan atau ruang lingkup Isytiqaq dimana kata-kata sebagian musytaq dan sebagian bukan musytaq. Pendapat ini didukung oleh Sibawaih, dan al-Zujjaaj. Sedangkan Ulama Modern berpendapat bahwa semua kata adalah musytaq. Ulama lain yang agak ekstrim mengatakan semua kata adalah asli, tidak dibentuk dan tidak diambil dari kata manapun. Pendapat ini didukung oleh Ibn Faris. Terlepas dari pro dan kontra tentang Isytiqaq ini, Ulama Bashrah juga mempunyai pendapat yang hampir senada dengan ulama sebelumnnya, bahwa mashdar merupakan asal dari semua kata sedangkan Ulama Kuffah berpendapat bahwa fiil adalah bentuk asal semua kata.

Isytiqaq al-Kubbar/al-Nahat dalam aplikasinya terhadap Linguistik Moderen adalah singkatan yang dikenal dengan nama Akronim artinya mempersingkat atau memendekkan suatu kata dengan cara yang berbeda-beda; ada singkatan pada kata awal, di tengah dan pada kata akhrirnya. Seperti Sekolah Menengah Pertama disingkat menjadi SMP, Pendidikan Nasional disingkat menjadi Diknas, Hari Kebangkitan Nasional disingkat menjadi Harkitnas. Semua contoh di atas, tidak serta merta bisa diaplikasikan pada konteks kaedah isytiqaq yang terjadi pada kaidah Linguistik Arab. 
Salah seorang ulama yang menentang adanya Isytiqaq Kabir adalah Jalaluddin Suyuthi pengarang kitab alMuzhir fiy 'Ulum al-Lughah karena menurutnya sangat melelahkan dalam hal penerapannya dan terlalu dibuatbuat. Menurut hemat penulis, alasan Suyuthi ini agaknya karena Suyuthi termasuk penganut Mazhab Tauqifiy dimana menurutnya kita tidak bisa merubah ketentuan yang sudah dibuat oleh para ulama sebelumnya karena akan merusak hakikat bahasa.

\section{PENUTUP}

Berdasarkan uraian di atas, bahwa fenomena isytiqaq menjadi karakteristik dan keistimewaan Bahasa Arab yang melekat yang sudah ada sejak dahulu, dimana Ulama Bahasa Arab telah

\section{DAFTAR RUJUKAN}

Akhyar Hanif, 2010, Fiqh al-Lughah: Refleksi Pemikiran Kebahasaan Jalaluddin al-Suyuthi, Batusangkar: Stain Batusangkar Press, Cet.I (sesuiakan dengan pedoman penulisan Ta'dib).

'Aliy 'Abd al-Wahid Wafiy, 1962, Fikh al-Lughah, Kairo: Lajnah al-Bayan

Amil Badi' Ya'qub, Tp.Th, Fikh alLughah al-Arabiyyah wa Khashaisuha, Beirut: Dar alTsaqafah al-Islamiyyah.

Hamid Shadiq Qunaibiy, 2000, alMa'ajim wa al-Mushthalahat, Mabahits fiy al-Musthalahat wa al-Ma'ajim wa aal-Ta'rib, Saudi Arabia: al-Dar al-Sa'udiyah, Cet I.

Ibn Faris, 1993, al-Shahibiy fiy fikh alLughah al-'Arabiyah wa concern dan fokus dalam menjelaskannya. Hal ini dibuktikan adanya bab khusus yang membahas tentang Istiqaq, seperti isytiqaq shagir, Isytiqaq Kabir/al-qalb, Isytiqaq Akbar/al-badal dan Istiqaq Kubbar/al-Nahat yang dituangkan oleh Ibn Jinniy dalam Kitabnya al-Khashais dan Ibn Faris dalam kitabnya al-Shahibiy serta Jalauddin alSuyuthi dalam kitabnya al-Muzhir Fiy 'Ulum al-Lughah.

Dalam konteks kekinian, isytiqaq atau derivasi dikenal dengan Etimologi artinya Ilmu yang mengkaji asal-usul terbentuknya sebuah kata. Namun kajian linguistik modern dan Linguistik Arab mempunyai spesifikasi yang bervariasi walaupun sisi kesamaan dan kemiripan terbentuknya suatu kata menjadi kata lain ada kesamaannya.

Masailiha wa Sunana al- 'Arab fiy Kalamiha, Beirut: Maktabah alMa'arif, Cet. I.

Ibn Jinniy, 1952, al-Khashais, Mesir: Dar al-Kutub.

Louis Ma'luf, 1992, al-Munjid fiy alLughah wa al-A'lam, Beirut: Dar al-Masyriq, Cet XXXII.

Muhammad Mubarak, Tp.Th, Fikh alLughah wa Khashaish al'Arabiyyah, Damaskus: Dar alFikr, Cet I.

Ramadhan Abd al-Tawwab, Tp.Th, Fushul fiy Fikh al-'Arabiyah, Kairo: Maktabah al-Khanijiy, Cet. VIII.

Subhi Shaleh, Tp.Th, Dirasat fiy Fikh alLughah, Beirut: al-Ahliyyah, Cet.II. 